\title{
Soil Classification in Yigossa Watershed, Lake Tana Basin, Highlands of Northwestern Ethiopia
}

\author{
Gizachew Ayalew ${ }^{1}$, Yihenew G. Selassie ${ }^{2}$, Eyasu Elias ${ }^{3} \&$ Chiristy Van Beek ${ }^{4}$ \\ ${ }^{1}$ Amhara Design and Supervision Works Enterprise (ADSWE), Bahir Dar, Ethiopia \\ ${ }^{2}$ College of Agriculture and Environmental Sciences, Bahir Dar University, Bahir Dar, Ethiopia \\ ${ }^{3}$ Capacity Building for Scaling up of Evidence-Based Best Practices in Agricultural Production in Ethiopia \\ (CASCAPE) project, Addis Ababa, Ethiopia \\ ${ }^{4}$ ALTERA, Wagenigen University and Research, Wagenigen, The Netherlands \\ Correspondence: Yihenew G. Selassie, College of Agriculture and Environmental Sciences, Bahir Dar \\ University, Bahir Dar, Ethiopia. E-mail: yihenewgs@gmail.com
}

Received: August 31, 2014 Accepted: September 18, 2014 Online Published: December 15, 2014

doi:10.5539/jas.v7n1p106 URL: http://dx.doi.org/10.5539/jas.v7n1p106

\begin{abstract}
A study was conducted in 2013 at Yigossa watershed, Northwestern Ethiopia to study the morphological and physicochemical characteristics and classify soils using FAO/WRB criteria. Four soil profiles, at slope classes of $0-2,2-5,5-8$ and $8-15 \%$ were described in-situ using FAO/WRB guideline. Soil samples were collected from pedogenic horizons and analyzed for soil color, bulk density, texture, structure, $\mathrm{pH}$, organic carbon (OC), total nitrogen (TN), available phosphorus (AvP), cation exchange capacity (CEC), exchangeable bases $\left(\mathrm{Ca}^{2+}, \mathrm{Mg}^{2+}\right.$, $\mathrm{K}^{+}$and $\mathrm{Na}^{+}$) and percent base saturation (PBS). FAO/WRB soil classification legend was used to classify the soils. Geographical Information System (GIS) software was employed to produce slope and soil maps of the watershed. Results of the study indicated that Yigossa soil profile No. 4 and No. 2 (i.e., YSP-4 and YSP-2) were very shallow $(<30 \mathrm{~cm})$ and moderately shallow $(50-100 \mathrm{~cm})$, respectively; whereas profile No. 1 and No. 3 (i.e., YSP-1 and YSP-3) were very deep (> $200 \mathrm{~cm}$ ). Surface soil color was 5YR4/3 for YSP-1 and 2.5YR3/3 for YSP-2 and it was 10YR4/2 and 10YR 2/1 for YSP-3 and YSP-4, respectively. All profiles, except YSP-4, were clay in texture. Highest and lowest bulk density values of $1.48 \mathrm{~g} \mathrm{~cm}^{-3}$ in YSP-3, and $0.7 \mathrm{~g} \mathrm{~cm}^{-3}$ in YSP-1 and YSP-4 were recorded. Highest OC $(2.3 \%)$ and TN $(0.2 \%)$ were registered at the surface of YSP-3. Highest CEC $\left(36.2 \mathrm{cmol}_{\mathrm{c}} \mathrm{kg}^{-1}\right)$ and PBS (83\%) were recorded from subsurface horizons of YSP-3. Generally, YSP-1, YSP-2, YSP-3 and YSP-4 were identified as Nitisols, Luvisols, Gleysols and Regosols at 2-5, 5-8, 0-2 and 8-15\% slope classes, respectively.
\end{abstract}

Keywords: soil analysis, soil classification, soil profile, slope, Yigossa watershed, Northwestern Ethiopia

\section{Introduction}

Agriculture is the mainstay of the Ethiopia's economy where its production is highly dependent on natural resources (Akililu \& Graaff, 2007). However, the country remained unable to feed its people (Fasil, 2002). Soil resources significantly affect agricultural productivity. On the other hand, soil degradation caused by a number of socio-economic factors such as deforestation, over cultivation, over population, over grazing and other inappropriate farming practices reduced productive capacity of the soil (Gete \& Hurni, 2001; Rajesh et al., 2003; Kumar et al., 2014).

Detailed soil data and information is inevitable to address the soil evaluation, fertility guidance and advise land users on how to use the land in the best possible way (Burrough, 1996). In other words, non-use of soil data and information could bring soil and soil-related environmental problems like nutrient depletion (Onweremadu, 2006), compaction, flooding and poor crop yields (Zinck, 1990; Chintala et al., 2014; Prasad, 2014). The current soil map of Ethiopia is not comprehensive enough to provide detailed site specific soil data and information for policy makers and draw development planning at watershed level. Therefore, the quality of the map increasingly used for agriculture land suitability analysis is questionable.

The existing soil map of Ethiopia has limited use in supporting soil conservation and management interventions. Therefore, to use and manage different soil types, understanding the properties, characteristics and classification 
of the soils is required. In addition, most current knowledge and skills about the soils resided with farmers and agricultural advisors obtained through experience have not easily been documented to allow the transfer of soil and crop technologies elsewhere. Moreover, the presence of different soil types requires locally specific management methods. Therefore, it was important to collect reliable soil data and information for regional and site specific uses.

Improved understanding of the genesis of soils and their relationships leads to improvements in their use and management. However, little emphasis has been given to soil genesis and classification studies in the highlands of Ethiopia (Mitiku, 1987). The call for providing this soil information is more demanding for the Yigossa watershed in Dera district than before because of the problem arising from misuse of land, resulting in soil degradation. Hence, much research is needed to be done at watershed level to understand the soil genesis and classification for providing better exploitation of research investigations (Mesfin, 1998). Therefore, the main objective of this research was to study the morphological and physicochemical characteristics, and classify the soils of Yigossa watershed.

\section{Materials and Methods}

\subsection{Description of the Study Watershed}

Yigossa watershed is located in Dera district, Amhara National Regional State, at about $30 \mathrm{~km}$ far from the regional capital, Bahir Dar (Figure 1). The study watershed is geographically positioned within $11^{\circ} 46^{\prime} 24.5^{\prime \prime}-11^{\circ} 48^{\prime} 40.8^{\prime \prime}$ latitude, $37^{\circ} 30^{\prime} 40.3^{\prime \prime}-37^{\circ} 34^{\prime} 15.6^{\prime \prime}$ longitude and has altitudes ranging from 1802 to 1970 meters above sea level. The total area is about 1092.68 ha of land including Metsele, Zhara and Wenchite kebeles. It is also dominated by a land with $2-5 \%$ slope and intensive crop cultivation. The foot slope borders Lake Tana, the source of the Blue Nile River.

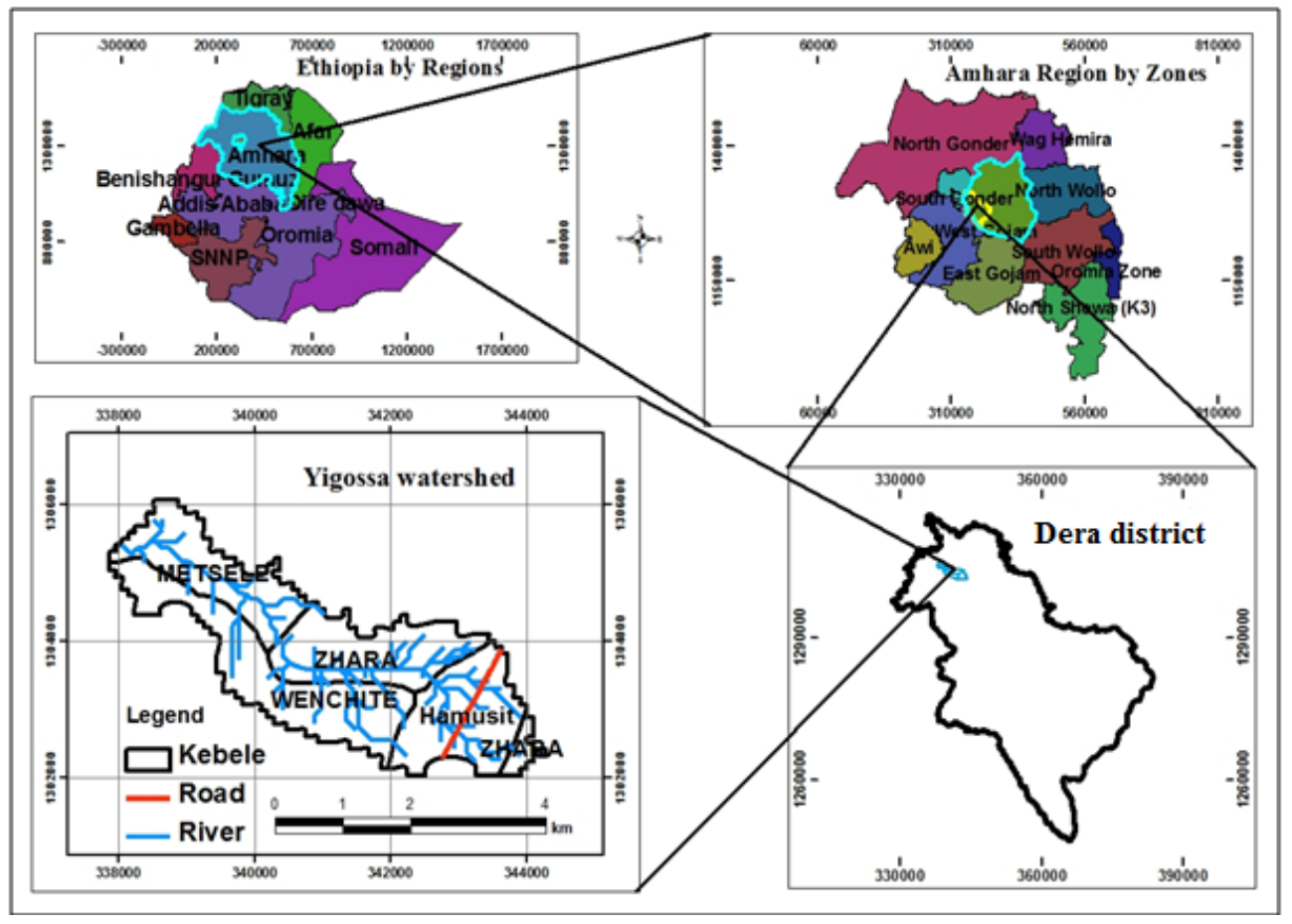

Figure 1. Location map of the study watershed

The agro-climatic resource of the Amhara Region is available at scale of 1:250,000 developed from long-term records (1994-2003) of annual rainfall and temperature data collected from Bahir Dar Metrological Station. Accordingly, annual mean minimum and maximum temperature of the watershed are $17.5{ }^{\circ} \mathrm{C}$ and $20{ }^{\circ} \mathrm{C}$, respectively; whereas the average annual rainfall ranges from 1200-1500 mm (DSA \& SCI, 2006). Based on the traditional agro-climatic classification of Ethiopia, the climate of the watershed is moist tepid.

The geological formation of the watershed generally belongs to the basaltic Tapp Series of the Tertiary volcanic eruptions in general and Gunna mountain shield volcano in specific. The volcano corresponds to the eruptive 
events that occurred during the early Miocene to Pliocene period and classified in the shield group basalt (BCEOM, 1999; Kieffer et al., 2004). The common litho type for this material is basaltic origin. The soil of the watershed was previously characterized by Luvisols, clay in texture with depth of over $150 \mathrm{~cm}$ at scale of 1:250,000 (DSA \& SCI, 2006).

The farming system of the watershed can be characterized as crop-livestock mixed with intensive crop cultivation. Intensive cultivated areas occur on gentle sloping areas where as moderately cultivated areas are found steeply sloping areas. Maize (Zea mays L.), teff (Eragrostis tef Zucc.), finger millet (Eleusine coracana L.) and rice (Oryza sativa L.) are the major crops grown. Cattle, equine, and small ruminants graze on communal grazing areas during the rainy season while crop fields are privately owned. The natural vegetation has almost been completely cleared. However, trees and shrubs such as eucalyptus spp, juniperus spp, acacia spp, bissana (Croton macrostachys L.) and warka (Ficus vasta L.) as a homestead plantation are the most common species in the watershed.

\subsection{Methods of the Study}

\subsubsection{Soil Profile Description}

Yigossa watershed was stratified into four slope classes as there is strong relationship between slope and soil types and their characteristics (FAO, 1998). The slope classes were 0-2\% (foot slope), 2-5\% (gentle sloping), 5-8 $\%$ (sloping) and $8-15 \%$ (strongly sloping). Slopes maps were extracted from digital elevation model (DEM) having $30 \times 30 \mathrm{~m}$ resolution with the help of Geographical Information System (GIS) software. Based on soil color, texture and slope, tentative major soil types and their boundaries were identified and delineated in the field by auguring through intensive traversing and purposive soil survey method. In addition, soil depth from road cut, gullies and river cuts were used to locate delineation points. Soil profiles having a depth of $2 \mathrm{~m}$ and a width of $1 \mathrm{~m}$, unless limited or impracticable due to stoniness, were opened and in situ, described for soil morphological and physicochemical characterizations in each slope classes following FAO (2006) guideline. A total of 8 undisturbed and 19 disturbed soil samples were collected and analyzed in soil laboratory. The soil profile pit sites are presented in Figure 2.

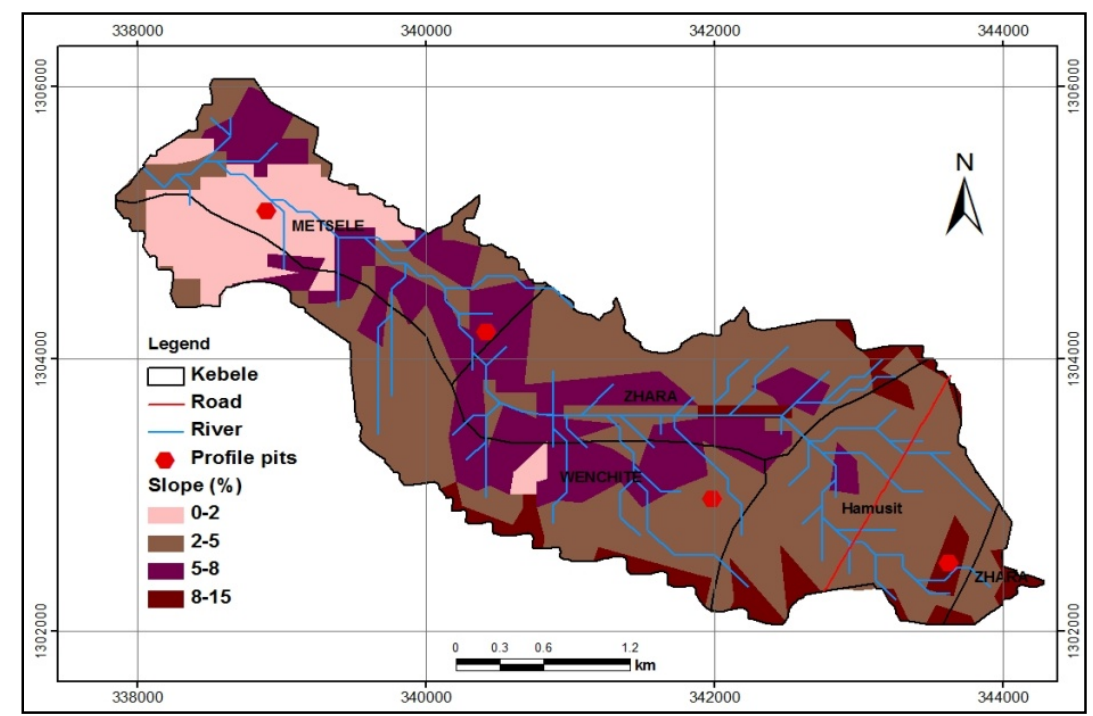

Figure 2. Soil profile locations in different slope classes

\subsubsection{Soil Analysis}

The soil samples collected from the soil profiles were air dried at room temperature and ground to pass through 2 $\mathrm{mm}$ sieve for all the soil parameters except for total nitrogen (TN) and organic carbon (OC) that passed through $0.5 \mathrm{~mm}$ sieve. Soil bulk density was determined by the method as described in Black (1965) where first undisturbed soil samples taken by core sampler of known volume (height $5 \mathrm{~cm}$ and diameter $7.2 \mathrm{~cm}$ ) weighed at field moisture condition. The soil samples were then oven dried at $105^{\circ} \mathrm{C}$ for 72 hours until constant weight was obtained and the oven dried samples were weighed again. Bulk density was then computed by dividing the weight of oven dried soil samples to the volume of the sampler. Soil texture was determined by the hydrometer 
method as described in Bouyoucos (1962). Hydrogen peroxide was used to destroy organic matter and sodium hexa-metaphosphate as dispersing agent. Then, hydrometer readings after 40 seconds and 2 hours were used to determine the silt plus clay, and clay particles in suspension, respectively, whereas the percent of silt was calculated from the difference. Finally, soil textural classes were determined following the textural triangle of USDA system as described in Rowell (1997). Soil pH was measured potentiometrically using a digital pH meter in the supernatant suspension of 1:2.5 (soil: water ratio) (Chintala et al., 2012a).

The organic carbon (OC) content was analyzed following the wet digestion method described in Walkley and Black (1934) which involves digestion of the OC in the soil samples with potassium dichromate in sulphuric acid solution. The Kjeldahl procedure was followed for the determination of total nitrogen (TN) that follows oxidizing of the same with concentrated sulphuric acid and converting the nitrogen in the organic compounds into ammonium sulphate during the oxidation (Bremner \& Mulvaney, 1982). Available phosphorus (P) was determined by Bray II method in which available $\mathrm{P}$ was determined by shaking the soil sample with extracting soil solution of $0.3 \mathrm{~N}$ ammonium fluoride in $0.1 \mathrm{~N}$ hydrochloric acid as described in Bray and Kurtz (1945). The available P extracted then was measured by spectrophotometer (Murphy \& Riley, 1962). Exchangeable bases of the soils were extracted by excess ammonium acetate $\left(1 M \mathrm{NH}_{4} \mathrm{OAc}\right.$ at $\left.\mathrm{pH} 7\right)$ solution and measured by atomic absorption spectrophotometer $\left(\mathrm{Ca}^{2+}\right.$ and $\left.\mathrm{Mg}^{2+}\right)$ and flame photometer $\left(\mathrm{Na}^{+}\right.$and $\left.\mathrm{K}^{+}\right)$(Chintala et al., 2012a; Chintala et al., 2012b). The cation exchange capacity (CEC) was determined from ammonium-saturated samples that were subsequently replaced by $\mathrm{Na}^{+}$from a percolating sodium chloride solution (Chintala et al., 2013a). The excess salt was removed by $96 \%$ ethanol and the $\mathrm{NH}_{4}{ }^{+}$that is displaced by $\mathrm{Na}^{+}$was measured by the Kjeldahl procedure (Chapman, 1965). The percentage of base saturation (PBS) of the soils was computed by dividing the concentration of exchangeable bases $\left(\mathrm{Ca}^{2+}, \mathrm{Mg}^{2+}, \mathrm{K}^{+}\right.$and $\left.\mathrm{Na}^{+}\right)$by the value of CEC and multiplied by 100 (Bohn et al., 2001).

\subsubsection{Soil Classification}

Spatial soil classification was made at scale of 1:25,000 based on the information obtained from field soil profile morphological description and laboratory analysis result following FAO/WRB (1998) soil classification legend.

\section{Results and Discussion}

\subsection{Morphological and Physicochemical Characteristics of Yigossa Soil Profile-1}

The depth of Yigossa soil profile-1 (YSP-1) was very deep (> $200 \mathrm{~cm}$ ) (Table 1). This could be caused by deep diffuse of colluvial materials. Similar observations were made by Sawhney et al. (2000) and Mahapatra et al. (2000) in submontane tract of Punjab. The textural class varied fro heavy clay at the surface to clay in the underlying horizons. The bulk density (BD) ranged from $1.27 \mathrm{~g} \mathrm{~cm}^{-3}$ at the surface to $0.7 \mathrm{~g} \mathrm{~cm}^{-3}$ in the deep horizons which could be the migration of finer particles down the profile and accumulation of sandy particels ar the surface. The surface soil color was 5YR 4/3 for YSP-1 and 2.5YR 3/3 for YSP-2. Similarly, it was 10YR4/2 and 10YR2/1 in YSP-3 and YSP-4, respectively. The color patterns could be due to chemical and mineralogical composition, topographic position, textural makeup and moisture regimes of the soils (Fisher \& Binkley, 2000). The nutty angular blocky structure with shiny ped faces in the profile could reflect the existence of relative accumulation of clay and biological pedoturbation (FAO, 1998). Singh and Agrawal (2003) reported structural variability could be due to moisture, soil OM and clay contents. Heavier and higher clay contents recorded in the profile was corresponding to the finding of Getachew and Heluf (2007) in Nitisols of Ayehu research substation. The migration and accumulation of clay in the subsurface could be contributed by the in-situ synthesis of secondary clays, the weathering of primary minerals, or the residual concentration of clays from the selective dissolution of more soluble minerals (Buole et al., 2003).

Table 1. Soil physical characteristics of the YSP-1

\begin{tabular}{|c|c|c|c|c|c|c|c|}
\hline \multirow{2}{*}{$\begin{array}{c}\text { Depth } \\
(\mathrm{cm})\end{array}$} & \multicolumn{3}{|c|}{ Textural analysis $(\%)$} & \multirow{2}{*}{ Textural Class } & \multirow{2}{*}{$\mathrm{BD}\left(\mathrm{g} \mathrm{cm}^{-3}\right)$} & \multirow{2}{*}{ Color } & \multirow{2}{*}{ Structure } \\
\hline & Sand & Silt & Clay & & & & \\
\hline $0-25$ & 9 & 25 & 66 & Heavy clay & 1.27 & $5 \mathrm{YR} 4 / 3$ & Crumb \\
\hline $25-50$ & 3 & 17 & 80 & Clay & 0.9 & $7.5 \mathrm{YR} 4 / 3$ & Moderate angular blocky \\
\hline $50-75$ & 5 & 15 & 80 & Clay & 0.8 & $7.5 \mathrm{YR} 4 / 4$ & Moderate angular blocky \\
\hline $75-100$ & 3 & 15 & 82 & Clay & 0.7 & $7.5 \mathrm{YR} 4 / 6$ & Weak angular blocky \\
\hline $100-125$ & 7 & 13 & 80 & Clay & 0.7 & $7.5 \mathrm{YR} 5 / 4$ & Weak angular blocky \\
\hline $125-200^{+}$ & 3 & 15 & 82 & Clay & 0.7 & $7.5 \mathrm{YR} 5 / 3$ & Fine sub angular blocky \\
\hline
\end{tabular}


Higher percentage of sand was noticed at the surface indicating that larger in size and heavier in weight particles will not be easily illuviated down the soil profile. Silt exhibited an irregular trend with depth that could be due to temporal variation in weathering. The result was in agreement with the finding of Naidu (2002) in Karnataka. Similar results were also reported by Arun et al. (2002) in India. The decrease pattern of bulk density values in the profile reflects the general increase in contents of sand. This implies that no excessive compaction and restriction to root development (Werner, 1997). Similarly, Wakene (2001) reported that lower bulk densities were observed at subsurface in Bako area, Ethiopia.

As indicated in Table 2, the irregular pattern of $\mathrm{pH}$ values with soil depth might be due to downward movement of bases and clay adsorbed sporadically at different layers. This is in agreement with Buole et al. (2003). The organic carbon $(0.5 \%$ to $1.45 \%)$ and total nitrogen $(0.04 \%$ to $0.12 \%)$ contents varied irregularly with the soil depth. However, higher organic carbon and total nitrogen were recorded at the surface layer which could be attributed to the addition of farmyard manure and plant residues. Similar result was obtained by Getachew and Heluf (2007) in Ayehu, Ethipia. This pattern suggested that the main source of organic carbon and total nitrogen is organic matter. Available P at soil surface was greater than that of the subsoils due to greater biological activities, accumulation of organic materials and the increment of sand content. Similarly, Tekalign et al. (1988) reported that phosphorus is usually greater in the top soil than that of the subsoils due to sorption of the added P in the later. Higher CEC and organic carbon recorded at surface shows the strong association between organic carbon and CEC (Chintala et al., 2013a). However, lower CEC recorded at the sub soils could be due to the decrease in organic carbon and clay colloids to hold cations against leaching (Idoga \& Azagaku, 2005; Chintala et al., 2013a). The range of CEC indicates that the dominant clay mineral of the soil is low activity clay. The base saturation reflecting the dominance of basic cations is an indicator of illuviation of basic cations translocated after intensive leaching from the surfaces.

Table 2. Soil chemical characteristics of YSP-1

\begin{tabular}{|c|c|c|c|c|c|c|c|c|c|c|c|}
\hline \multirow{2}{*}{$\begin{array}{l}\text { Depth } \\
(\mathrm{cm})\end{array}$} & \multirow{2}{*}{$\mathrm{pH}\left(\mathrm{H}_{2} \mathrm{O}\right)$} & \multirow{2}{*}{$\begin{array}{l}\mathrm{OC} \\
(\%)\end{array}$} & \multirow{2}{*}{$\begin{array}{l}\mathrm{TN} \\
(\%)\end{array}$} & \multirow{2}{*}{$\begin{array}{c}\text { Ava. P } \\
\left(\mathrm{mg} \mathrm{kg}^{-1}\right)\end{array}$} & \multicolumn{5}{|c|}{ Exchangeable bases $\left(\mathrm{cmol}_{\mathrm{c}} \mathrm{kg}^{-1}\right)$} & \multirow{2}{*}{$\begin{array}{c}\mathrm{CEC} \\
\left(\mathrm{cmol}_{\mathrm{c}} \mathrm{kg}^{-1}\right)\end{array}$} & \multirow{2}{*}{$\begin{array}{l}\text { PBS } \\
(\%)\end{array}$} \\
\hline & & & & & $\mathrm{Ca}^{2+}$ & $\mathrm{Mg}^{2+}$ & $\mathrm{Na}^{+}$ & $\mathrm{K}^{+}$ & Sum & & \\
\hline $0-25$ & 5.56 & 1.4 & 0.12 & 7.90 & 10.53 & 1.05 & 0.30 & 1.54 & 13.41 & 20.6 & 65 \\
\hline $25-50$ & 5.76 & 0.9 & 0.08 & 5.37 & 9.81 & 1.29 & 0.19 & 2.45 & 13.74 & 18.0 & 76 \\
\hline $50-75$ & 5.36 & 0.5 & 0.04 & 3.78 & 9.80 & 1.16 & 0.07 & 2.45 & 13.48 & 18.4 & 73 \\
\hline $75-100$ & 5.54 & 0.8 & 0.07 & 4.25 & 10.32 & 1.23 & 0.14 & 2.56 & 14.26 & 19.4 & 74 \\
\hline $100-125$ & 5.15 & 0.9 & 0.07 & 5.25 & 9.58 & 1.21 & 0.07 & 2.42 & 13.27 & 16.6 & 80 \\
\hline $125-200^{+}$ & 5.16 & 0.6 & 0.05 & 2.66 & 9.16 & 0.91 & 0.01 & 2.10 & 12.18 & 18.8 & 65 \\
\hline
\end{tabular}

\subsection{Morphological and Physicochemical Characteristics of Yigossa Soil Profile-2}

As shown in Table 3, the depth of YSP-2 was moderately shallow $(50-100 \mathrm{~cm})$. Reddish brown color was found throughout the profile that could be due to low organic matter content and the occurrence of various hydrated iron oxide forms. The result was in conformity with the findings of Walia and Rao (1996) and Sidhu et al. (1994) at Uttar Pradesh in northern India. Moderate to strong granular and blocky soil structure observed within the profile could reflect the existence of clay. Clay soil texture class could be probably due to clay migration within the profile. The profile had high clay and base saturation greater than $35 \%$. This could be attributed to eluviations of clay size particles. The accumulation of clay in the subsurface could have been contributed by the in situ synthesis of secondary clays or the weathering of primary minerals from dissolution of more soluble minerals of coarse grains (Buole et al., 2003). The contents of silt were high in the profile and revealed an irregular decrease with depth. This decrease may reflect the weathering process of silt to clay size particles in the sub soils. As indicated in Table 3, the BD values of YSP-2 ranged from $1.14 \mathrm{~g} \mathrm{~cm}^{-3}$ at the surface to $1.00 \mathrm{~g} \mathrm{~cm}^{-3}$ in the sub surface suggesting a decrease in sand contents with increasing depth. This result was supported by Swarnam et al. (2004). Conversely, this result disagreed with Brady and Weil (2002) who indicated that bulk density increased with increasing soil depth. 
Table 3. Soil physical characteristics of YSP-2

\begin{tabular}{|c|c|c|c|c|c|c|c|}
\hline \multirow{2}{*}{$\begin{array}{l}\text { Depth } \\
(\mathrm{cm})\end{array}$} & \multicolumn{3}{|c|}{ Particle size analysis (\%) } & \multirow{2}{*}{ Textural Class } & \multirow{2}{*}{$\begin{array}{c}\mathrm{BD} \\
\left(\mathrm{g} \mathrm{cm}^{-3}\right)\end{array}$} & \multirow{2}{*}{ Color } & \multirow{2}{*}{ Structure } \\
\hline & Sand & Silt & Clay & & & & \\
\hline $0-15$ & 15 & 1.14 & 52 & Clay & 1.14 & $2.5 Y R 3 / 3$ & Strong granular \\
\hline $15-30$ & 7 & 1.07 & 80 & Clay & 1.07 & $2.5 \mathrm{YR} 3 / 4$ & Moderate angular blocky \\
\hline $30-45$ & 7 & 1.01 & 74 & Clay & 1.01 & $2.5 \mathrm{YR} 4 / 3$ & Fine angular blocky \\
\hline $45-70$ & 5 & 1.00 & 78 & Clay & 1.00 & $2.5 \mathrm{YR} 4 / 4$ & Weak angular blocky \\
\hline
\end{tabular}

As revealed in Table 4, the pH values of YSP-2 varied from 5.55 to 5.92 (slightly acidic) which could be due to the leaching of basic cations particularly $\mathrm{Ca}^{2+}$ and $\mathrm{Mg}^{2+}$. This is in agreement with the finding of Buole et al. (2003). The contents of soil organic carbon showed a similar pattern as $\mathrm{pH}$ values. This could be attributed to the vertical migration of finer organic colloids. It may also implicate presence of historically deposited organic matter. The lower content of organic carbon may indicate little return of decomposable matter from cultivated crops as well as existence of high rates of oxidation and degradation accentuated through long periods of cultivation. The low content of total nitrogen could be associated with degradation of total nitrogen content coupled with little nitrogen fertilization occurred in the area. This result is in line with the findings of Belay (1996) in Tigray region. The level of available $P$ was generally low (Table 4). This might be due to its fixation by $\mathrm{Al}$ and $\mathrm{Fe}$ in acidid soils (Tisdale et al., 2002). Cation exchange capacity varied from 16.2 to $22.2 \mathrm{cmol}_{\mathrm{c}} \mathrm{kg}^{-1}$ and showed an irregular variation with depth of the profile. Relatively higher $\mathrm{pH}$ and PBS values recorded at surface might be due to the accumulation of basic cations from weathering of its parent materials (Brady \& Weil, 2002). Similar observations were also made by Foth (1990) and Pillai and Natarajan (2004).

Table 4. Soil chemical characteristics of YSP-2

\begin{tabular}{|c|c|c|c|c|c|c|c|c|c|c|c|}
\hline \multirow{2}{*}{$\begin{array}{l}\text { Depth } \\
(\mathrm{cm})\end{array}$} & \multirow{2}{*}{$\mathrm{pH}\left(\mathrm{H}_{2} \mathrm{O}\right)$} & \multirow{2}{*}{$\begin{array}{l}\mathrm{OC} \\
(\%)\end{array}$} & \multirow{2}{*}{$\begin{array}{l}\mathrm{TN} \\
(\%)\end{array}$} & \multirow{2}{*}{$\begin{array}{l}\text { Available P } \\
\left(\mathrm{mg} \mathrm{kg}^{-1}\right)\end{array}$} & \multicolumn{5}{|c|}{ Exchangeable bases $\left(\mathrm{cmol}_{\mathrm{c}} \mathrm{kg}^{-1}\right)$} & \multirow{2}{*}{$\begin{array}{c}\mathrm{CEC} \\
\left(\mathrm{cmol}_{\mathrm{c}} \mathrm{kg}^{-1}\right)\end{array}$} & \multirow{2}{*}{$\begin{array}{l}\text { PBS } \\
(\%)\end{array}$} \\
\hline & & & & & $\mathrm{Ca}^{2+}$ & $\mathrm{Mg}^{2+}$ & $\mathrm{Na}^{+}$ & $\mathrm{K}^{+}$ & Sum & & \\
\hline $0-15$ & 5.92 & 0.8 & 0.07 & 4.37 & 11.17 & 0.93 & 0.14 & 2.23 & 14.47 & 18.80 & 77 \\
\hline $15-30$ & 5.71 & 0.6 & 0.05 & 5.49 & 10.55 & 1.23 & 0.58 & 0.88 & 13.24 & 18.40 & 72 \\
\hline $30-45$ & 5.55 & 0.5 & 0.05 & 3.6 & 9.55 & 1.12 & 0.74 & 0.76 & 12.17 & 22.20 & 55 \\
\hline $45-70$ & 5.68 & 0.6 & 0.05 & 4.6 & 10.1 & 0.96 & 0.27 & 0.79 & 12.12 & 16.20 & 75 \\
\hline
\end{tabular}

\subsection{Morphological and Physicochemical Characteristics of Yigossa Soil Profile-3}

The depth of YSP-3 was very deep (> $200 \mathrm{~cm})$ and profile development varied from 25 to $125 \mathrm{~cm}$ soil layers (Table 5). This may be caused by deep diffuse of alluvial-colluvial materials. The soil color varied from grayish yellow brown (10YR4/2) to black (10YR2/1) that might be due to the presence of organic matter and hydrated iron oxides (FAO, 1998) and the extended saturation by water, high organic matter and reduced iron content. This result was in line with the findings of Mohammed et al. (2005) in Chercher highlands of Ethiopia. The greenish and bluish shades are attributed to the influences of various iron-based compounds. The mottling or redoximorphic features observed in the subsoil may be due to loss or gain of iron and/or manganese (Fanning \& Fanning, 1989). According to Foth (1990), reddish color is also due to the presence of oxidized iron compounds. Hence, the possible reason for the relative dark color could be due to differences in forms of iron oxide. The brown color observed in the profile indicates low contents of OM that lightens its color. Organic matter and clay in the profile might be the reasons why the topsoil and subsoil were structurally developed and stabilized. The desirable effects of $\mathrm{OM}$ in the formation of soil granules and in stabilizing soil aggregates have also been reported (Daniel et al., 2000). The amount of clay of YSP-3 ranged from 52 to $60 \%$ with clay texture. Its bulk density values varied between 1.2 to $1.48 \mathrm{~g} \mathrm{~cm}^{-3}$ at subsurface and surface, respectively. This implies that no excessive compaction and restriction to root development (Werner, 1997). Higher bulk density recorded at the surface could be caused by repetitive cultivation and intensive reduction processes in the surface layer and translocation and precipitation of iron and manganese compounds in the subsoil (FAO, 1998). 
Table 5. Soil physical characteristics of YSP-3

\begin{tabular}{cccccccc}
\hline \multirow{2}{*}{$\begin{array}{c}\text { Depth } \\
(\mathrm{cm})\end{array}$} & \multicolumn{2}{c}{ Particle size analysis $(\%)$} & Textural class & BD $\left(\mathrm{g} \mathrm{cm}^{-3}\right)$ & Color & Structure \\
\cline { 2 - 4 } & Sand & Silt & Clay & & & & \\
\hline $0-25$ & 5 & 37 & 58 & Clay & 1.48 & 10 YR4/2 & Strong angular blocky \\
$25-50$ & 7 & 33 & 60 & Heavy clay & 1.38 & 10 YR3/2 & Moderate angular blocky \\
$50-75$ & 11 & 31 & 58 & Clay & 1.3 & 10 YR3/4 & Fine angular blocky \\
$75-200^{+}$ & 13 & 35 & 52 & Clay & 1.2 & $10 Y R 2 / 1$ & Weak angular blocky \\
\hline
\end{tabular}

Soil organic carbon (OC) and total nitrogen (TN) showed irregular pattern with depth at YSP-3 (Table 6). However, its content recorded at the surface was relatively higher than the sub-surface. This finding was in agreemnt with the works of Mitiku (2000); Abayneh (2001) and Ahmed (2002). In other study, OC in the soils of inter-hill valleys exhibited an irregular trend with depth (Bhaskar et al., 2004). The lower concentration of available $\mathrm{P}$ in the subsoil is attributed to the increment of clay content and clay type which can cause high $\mathrm{P}$ fixation and less mineralization of organic matter. Available $\mathrm{P}$ can increase as organic $\mathrm{P}$ is mineralized or when sorbed P becomes available (Chintala et al., 2013b). On other hand, available P at soil surface was greater than that of the subsoils due to sorption of the added $\mathrm{P}$, greater biological activities, high inherent $\mathrm{P}$ content of the parent material and increased mineralization. This result was in line with the findings of Tekalign et al. (1988). Based on FAO (1998) ratings, the PBS values were high (> 50\%) throughout the profile. Higher pH values and PBS of sub surface might be due to less $\mathrm{H}^{+}$ions released and influx of basic cations from the adjacent slopes. This is in agreement with Buole et al. (2003) and Chintala et al. (2010).

Table 6. Soil chemical characteristics of YSP-3

\begin{tabular}{|c|c|c|c|c|c|c|c|c|c|c|c|}
\hline \multirow{2}{*}{$\begin{array}{l}\text { Depth } \\
(\mathrm{cm})\end{array}$} & \multirow{2}{*}{$\mathrm{pH}\left(\mathrm{H}_{2} \mathrm{O}\right)$} & \multirow{2}{*}{$\begin{array}{l}\mathrm{OC} \\
(\%)\end{array}$} & \multirow{2}{*}{$\begin{array}{l}\mathrm{TN} \\
(\%)\end{array}$} & \multirow{2}{*}{$\begin{array}{l}\text { Avaialable P } \\
\quad\left(\mathrm{mg} \mathrm{kg}^{-1}\right)\end{array}$} & \multicolumn{5}{|c|}{ Exchangeable bases $\left(\mathrm{cmol}_{\mathrm{c}} \mathrm{kg}^{-1}\right)$} & \multirow{2}{*}{$\begin{array}{c}\mathrm{CEC} \\
\left(\mathrm{cmol}_{\mathrm{c}} \mathrm{kg}^{-1}\right)\end{array}$} & \multirow{2}{*}{$\begin{array}{l}\text { PBS } \\
(\%)\end{array}$} \\
\hline & & & & & $\mathrm{Ca}^{2+}$ & $\mathrm{Mg}^{2+}$ & $\mathrm{Na}^{+}$ & $\mathrm{K}^{+}$ & Sum & & \\
\hline $0-25$ & 5.77 & 2.3 & 0.2 & 10.50 & 15.08 & 3.84 & 0.60 & 0.82 & 20.34 & 32.8 & 62 \\
\hline $25-50$ & 7.12 & 0.7 & 0.06 & 2.78 & 20.68 & 4.78 & 1.15 & 0.84 & 27.44 & 34.6 & 79 \\
\hline $50-75$ & 7.12 & 1 & 0.08 & 2.31 & 18.89 & 4.45 & 1.15 & 0.86 & 25.35 & 33.8 & 75 \\
\hline $75-200^{+}$ & 8.30 & 0.5 & 0.04 & 0.37 & 21.68 & 4.84 & 2.50 & 0.91 & 29.93 & 36.2 & 83 \\
\hline
\end{tabular}

\subsection{Morphological and Physicochemical Characteristics of Yigossa Soil Profile-4}

Profile YSP-4 had very shallow soil depth $(<30 \mathrm{~cm})$ with young age and/or slow soil formation by colluvial deposits (Table 7). The soil color of the surface was black (10YR 2/1) and the color becomes brownish black (10YR 3/2) down to depth indicating low in organic matter content. This finding was similar with the works of Belay (1996). The surface and subsurface had moderate granular and angular blocky structures due to organic matter and clay contents. The texture class varied from loam in the surface to clay loam in subsurface which was similar with the finding of DSA and SCI (2006) and Mohammed et al. (2005). The amount of clay increased with depth of the YSP-4 from $22 \%$ in the surface to $32 \%$ in the subsurface that shows stages of weathering and a presence of vertical movement of clay size particles.

Table 7. Soil physical characteristics of YSP-4

\begin{tabular}{cccccccc}
\hline \multirow{2}{*}{$\begin{array}{r}\text { Depth } \\
(\mathrm{cm})\end{array}$} & \multicolumn{2}{c}{ Particle size analysis $(\%)$} & Textural Class & BD $\left(\mathrm{g} \mathrm{cm}^{-3}\right)$ & Color & Structure \\
\cline { 2 - 4 } & Sand & Silt & Clay & & & & \\
\hline $0-15$ & 37 & 41 & 22 & Loam & 0.7 & 10YR 2/1 & Moderate granular \\
$15-30$ & 31 & 37 & 32 & Clay loam & 0.7 & 10YR 3/2 & Weak angular blocky \\
\hline
\end{tabular}

The $\mathrm{pH}$ values in YSP-4 revealed a decreasing trend with depth, ranging from 6.14 in the surface to 5.62 in the subsurface (Table 8). This suggested that lateral water transport was not a significant hydrologic process at this landscape and lateral transport of weathered solutes was minimal. The available P content varied from $5.37 \mathrm{mg}$ 
$\mathrm{kg}^{-1}$ in the surface to $20.1 \mathrm{mg} \mathrm{kg}^{-1}$ in the subsurface, indicating an increasing trend with depth of this soil. This could be due to the influence of soil parent material on $\mathrm{pH}$ value which eventually increased $\mathrm{P}$ availability (Chintala et al., 2012b; Chintala et al., 2013b). The result disagreed with the finding of Tekalign et al. (1988). Higher OC and TN might be due to nutrient bio-cycling (Ogunwale et al., 2002). Higher CEC could reflect the increased clay colloids. On the other hand, the low base saturation within the sub surface is likely a result of the lateral flow of water down slope and removing soluble cations. Percent base saturation (PBS) values of the surface and subsurface recorded were high (> 50\%). This may be due to weathering of parent materials, leaching and accumulation of basic cations from the adjacent mountains.

Table 8. Soil chemical characteristics of YSP-4

\begin{tabular}{|c|c|c|c|c|c|c|c|c|c|c|c|}
\hline \multirow{2}{*}{$\begin{array}{l}\text { Depth } \\
(\mathrm{cm})\end{array}$} & \multirow{2}{*}{$\mathrm{pH}\left(\mathrm{H}_{2} \mathrm{O}\right)$} & \multirow{2}{*}{$\begin{array}{l}\mathrm{OC} \\
(\%)\end{array}$} & \multirow{2}{*}{$\begin{array}{l}\mathrm{TN} \\
(\%)\end{array}$} & \multirow{2}{*}{$\begin{array}{l}\text { Available P } \\
\left(\mathrm{mg} \mathrm{kg}^{-1}\right)\end{array}$} & \multicolumn{5}{|c|}{ Exchangeable bases $\left(\mathrm{cmol}_{\mathrm{c}} \mathrm{kg}^{-1}\right)$} & \multirow{2}{*}{$\begin{array}{c}\mathrm{CEC} \\
\left(\mathrm{cmol}_{\mathrm{c}} \mathrm{kg}^{-1}\right)\end{array}$} & \multirow{2}{*}{$\begin{array}{l}\text { PBS } \\
(\%)\end{array}$} \\
\hline & & & & & $\mathrm{Ca}^{2+}$ & $\mathrm{Mg}^{2+}$ & $\mathrm{Na}^{+}$ & $\mathrm{K}^{+}$ & Sum & & \\
\hline $0-15$ & 6.14 & 1.2 & 0.11 & 5.37 & 12.81 & 3.32 & 0.04 & 1.27 & 17.44 & 26 & 67 \\
\hline $15-30$ & 5.62 & 1.1 & 0.09 & 20.1 & 12.54 & 3.52 & 0.26 & 1.12 & 17.44 & 30.8 & 57 \\
\hline
\end{tabular}

\subsection{Soil Classification}

Based on the field observations and laboratory analysis, Yigossa soil profile 1 (YSP-1) could be categorized as Nitisols following FAO/WRB (1998) soil classification legend. This is because Nitisols have clayey soil texture with nitic horizon, red in color, more than 30 percent clay with nutty blocky structure and shiny ped faces. This result was in harmony with the finding of Gete (2000) in Anjeni watershed. As per the soil classification legend, YSP-2 could be classified as Luvisols. This result was complaint with the finding of Belay (1996) because Luvisols are developed on very gently to gently sloping lands. In other study, at scale of 1:250,000, DSA and SCI (2006) indicated only Luvisols are found in Yigossa watershed. Whereas YSP-3 fulfills the criteria for Gleysols since the profile has gleyic characteristics evidenced by reductomorphic and oximorphic mottles conditioned by excessive wetness at shallow depth; heavy clay surface layers, no diagnostic horizons other than histic and mollic. Gleysols are generally considered to be comparatively fertile because of their fine soil texture, slow rate of organic matter decomposition and influx of ions. They have greater CEC and PBS of 50\% from soil surface. Finally, YSP-4 fulfils the criteria to call it as Regosols as they are unconsolidated mineral material, shallow to moderately deep soil, well drained and brown in color. These soils are loam, clayey in texture, moderate and angular blocky structure. This finding was in conformity with the conclusion of Gete (2000) that the upper slopes of Anjeni watershed that were covered Regosols. On the other hand, Kassa and Mulu (2012) showed that Regosols develop in association with Leptosols occurred at 3-8\% slope in Tigray Region. Hence, the soil types identified in the watershed were Luvisols (630.86 ha), Nitisols (256.95 ha), Gleysols (125.55 ha) and Regosols (79.33 ha) at slopes of 2-5, 5-8, 0-2 and 8-5\%, respectively (Figure 3).

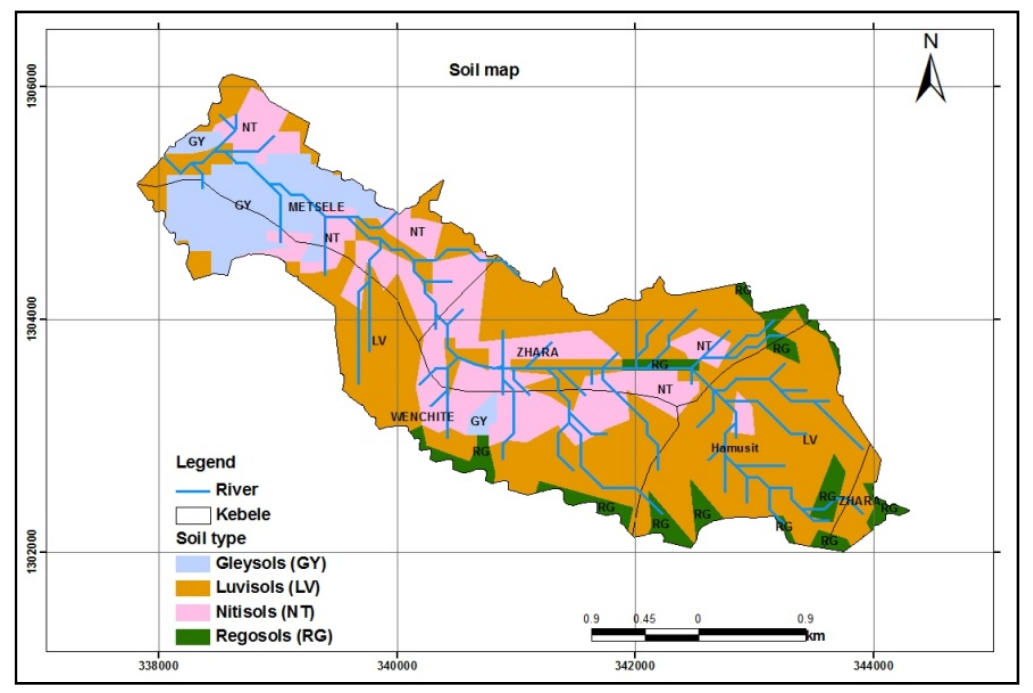

Figure 3. Major soil types identified in the study watershed 


\section{Conclusions}

On the basis of the soil profile descriptions and laboratory analysis, Nitisols, Luvisols, Gleysols and Regosols were identified in gentle slope, sloping, foot slope and strongly sloppy areas of Yigossa watershed, respectively. It is also possible to conclude that slope has a major effect on soil formation and its characteristics.

\section{Acknowledgements}

This study was part of the CASCAPE project on increasing agricultural productivity in Ethiopia. The CASCAPE project is funded by the Dutch Ministry of Foreign Affairs through the Embassy of the Kingdom of The Netherlands in Addis Ababa, Ethiopia.

\section{References}

Abayneh, E. (2001). Application of GIS for soil resource study in Ethiopia (pp. 162-169). Proceeding of the National Sensitization Workshop on Agrometrology and GIS. Addis Ababa, Ethiopia.

Ahmed, H. (2002). Assessment of Spatial Variability of Some Physicochemical Characteristics of Soils under Different Elevations and Land Use Systems in the Slopes of Mount Chilalo (M.Sc. Thesis, p. 104). Alemaya University, Ethiopia.

Akililu, A., \& Graaff De, J. (2007). Determinants of adoption and continued use of stone terraces for soil and water conservation in an Ethiopian highland watershed. Ecological Economics, 61, 294-302. http://dx.doi.org/10.1016/j.ecolecon.2006.01.014

Arun, K.V., Natarajan, S., \& Sivasamy, R. (2002). Characterization and classification of soils of lower Palar-Manimuthar watershed of Tamil Nadu. Agropedology, 12, 97-103.

BCEOM-French Engineering Consultants. (1999). Abbay River Basin Integrated Development Master Plan Project Phase 2 Report. Addis Ababa. Ethiopia.

Belay, T. (1996). Characteristics and landscape relationships of Vertisols and vertic Luvisols of Melbe Tigray in Ethiopia. SINET: Ethiopian Journal of Science, 19(1), 93-115.

Bhaskar, B. P., Saxena, R. K., Vadivelu, S., Baruah, U., Butte, P. S., \& Dutta, D. P. (2004). Pedogenesis in high attitude soils of Meghalaya Plateau. Agropedology, 14, 9-23.

Black, C. A. (1965). Methods of Soil Analysis Part II. Chemical and microbiological characteristics. Agronomy Monograph No. 9 (pp. 18-25), American Society of Agronomy, Inc. Madison, Wisconsin, USA.

Bohn, H. L., McNeal, B. L., \& O’Connor, G. A. (2001). Soil Chemistry (3rd ed.). John Wiley and Sons Inc., USA.

Bouyoucos, G. J. (1962). Hydrometer method improved for making particle-size analysis of soils. Agronomy Journal, 54, 463-465. http://dx.doi.org/10.2134/agronj1962.00021962005400050028x

Brady, N. C., \& Weil, R. R. (2002). The Nature and Properties of Soils. Prentice-Hall, New Jersey.

Bray, R. H., \& Kurtz, L. T. (1945). Determination of total organic and available forms of phosphorus in soils. Soil Society, 59, 39-45. http://dx.doi.org/10.1097/00010694-194501000-00006

Bremner, J. M., \& Mulvaney, C. S. (1982). Total nitrogen. In A. L. Page, R. H. Miller \& D. R. Keeney (Eds.), Methods of soil analysis. II. Chemical and microbiological properties (Agronomy 9, pp. 595-624). Agronomy Inc. Madison, Wisconsin.

Buole, S. W., Hole, F. D., McCracken, R. J., \& Southard, R. J. (2003). Soil Genesis and Classification (4th ed., p. 527). Panima Publishing Corporation, New Delhi, Bangalore.

Burrough, P. A. (1996). Opportunity and Limitation of GIS Based Modeling of Solute Transport at the Regional Scale. In D. L. Corwi \& K. Loage (Eds.), Application of GIS to the Modeling of Non-point source pollutants in the Vadose Zone. SSSA, Madison, WI.

Chapman, H. D. (1965). Cation Exchange Capacity. In C. A. Black (Ed.), Methods of soil analysis, Agronomy 9 (pp. 891-901). Inc. Madison, Wisconsin.

Chintala, R., McDonald, L. M., \& Bryan, W. B. (2012a). Optimization of water potential and nutrient levels for Kentucky bluegrass-white clover mixture on acidic soils. Biotechnology, Agronomy, Society and Environment, 16, 167-177. 
Chintala, R., McDonald, L. M., \& Bryan, W. B. (2012b). Effect of soil water and nutrients on productivity of Kentucky bluegrass systems in acidic soils. Journal of Plant Nutrition, 35, 288-303. http://dx.doi.org/10.1080/01904167.2012.636131

Chintala, R., Djira, G., Devkota, M., Prasad, R., \& Kumar, S. (2014). Modeling the effect of temperature and precipitation on crop residue potential for the North Central Region of the United States. Agricultural Research. http://dx.doi.org/10.1007/s40003-014-0099-5

Daniel, P. R., Alvin, S. J. M., \& Santos, D. (2000). Alfafa root and shoot mulching effect on soil hydraulic properties and aggregation. Soil Science Society of America Journal, 64, 725-731. http://dx.doi.org/10.2136/sssaj2000.642725x

Development Studies Associates (DSA), \& Shawel Consult International (SCI). (2006). Potential Survey, Identification of Opportunities and Preparations of Projects Profiles and Feasibility Studies. Addis Ababa, Ethiopia.

Fanning, S., \& Fanning, C. M. (1989). Soil Morphology, Genesis and Classification (pp. 91-264). John Wiley and Son Publishers, N.Y.

FAO. (1998). Guidelines on Land Evaluation for Rainfed Agriculture. Soils Bulletin (No. 52). FAO, Rome, Italy.

FAO. (2006). Guidelines for Soil Description (p. 70). FAO, Rome, Italy.

FAO/WRB. (1998). World Reference Base for Soil Resources. World Soil Resource Report (No. 84, p. 88). FAO, Rome,

Fasil, K. (2002). Analysis of Yield Gap for Wheat Cultivation in the Highlands of North Ethiopia (Ph.D. Thesis). Gent University, Belgium.

Fisher, P., \& Binkley, P. (2000). Fuzzy modelling. In S. Openshaw \& R. J. Abrahart (Eds.), Geocomputation (pp. 161-186). Taylor and Francis, London.

Foth, H. D. (1990). Fundamentals of Soil Science (8th ed., p. 374). John Wiley and Sons Inc.

Getachew, F., \& Heluf, G. (2007). Characterization and fertility status of the soils of Ayehu research substation in Northern highlands of Ethiopia. East African Journal of Sciences, 1(2), 160-169.

Gete, Z. (2000). Landscape Dynamics and Soil Erosion Process Modeling in the North-western Ethiopian Highlands (Ph.D. dissertation, p. 196). African Studies Series A16, Bern, Switzerland.

Gete, Z., \& Hurni, H. (2001). Implications of land use and cover dynamics for mountain resource degradation in the Northwestern Ethiopian highlands. Mountain Research and Development, 21(2), 184-191. http://dx.doi.org/10.1659/0276-4741(2001)021\%5B0184:IOLUAL\%5D2.0.CO;2

Idoga, S., \& Azagaku, D. E. (2005). Characterization and classification of soils of Janta Area in Plateau State of Nigeria. Nigerian Journal of Soil Science, 15, 116-122.

Kassa, T., \& Mulu, H. (2012). Land suitability characterization for crop and fruit production of midlands of Tigray in Ethiopia. ISSN, 4(1), 64-76.

Kieffer, B., Arndt, N., Lapierre, H., Bastien, F., Bosch, D., Pecher, A., ... Meugniot, C. (2004). Flood and shield from Ethiopia: Magmas from the African supper swell. Journal of Petrology, 45, 793-834. http://dx.doi.org/10.1093/petrology/egg112

Kumar, S., Nakajima, T., Mbonimpa, E. G., Gautam, S., Somireddy, U. R., Kadono, A., ... Fausey, N. (2014). Long-term tillage and drainage influences on soil organic carbon dynamics, aggregate stability, and carbon yield. Soil Science \& Plant Nutrition, 60(1), 108-118. http://dx.doi.org/10.1080/00380768.2013.878643

Mahapatra, S. K., Walia, C. S., Sidhu, G. S., Rana, K. P. C., \& Tassem, Lal. (2000). Characterization and classification of soils of different physiographic units in the sub-humid ecosystem of Kashmir region. Indian Society Soil Science, 48(3), 575-577.

Mesfin, A. (1998). Nature and Management of Ethiopian Soils (p. 272). Alemaya University of Agriculture, Ethiopia.

Mitiku, B. (2000). Study on Some Important Physicochemical Characteristics of Gnaro Plantation and Natural Juniperous Forest Soils of Borena (M.Sc. Thesis, p. 112). Alemaya University, Ethiopia.

Mitiku, H. (1987). Genesis, Characteristics and Classification of the soils of the Central Highlands of Ethiopia (Ph.D. Thesis, p. 399). The State University of Ghent, Belgium. 
Mohammed, A., Roux, P. A. L., Barker, C. H., \& Heluf, G. (2005). Morphological and physicochemical properties of soils of Jelo micro-catchment in the Chercher highlands of Eastern Ethiopia. Ethiopian Journal of Natural Resources, 7(1), 55-81.

Murphy, \& Riley. (1962). Principles of Soil Mechanics and Foundation Engineering. 5th UBS Publisher's Distributer Ltd.

Naidu, L. G. K. (2002). Characterization of sugarcane soils of Karanataka. Agropedology, 12, 157-163.

Ogunwale, J. A., Olaniyan, J. O., \& Aduloju, M. O. (2002). Morphological, physicochemical and clay mineralogical properties of soil overlying basement complex rocks in Ilorin East Nigeria. Moor Journal of Agricultural Research, 3(21), 147-164.

Onweremadu, E. U. (2006). Application of Geographic Information System (GIS) on soil landuse and soil-related environmental problems in Southern Nigeria (Ph.D Thesis, p. 472). University of Nigeria.

Pillai, M. Y., \& Natarajan, A. (2004). Characterization and classification of dominant soils of parts of Garakahalli watershed using remote sensing technique. Mysore Journal of Agriculture Science, 38, 193-200.

Prasad, R. (2014). Using nitrogen and phosphorus budgets as effective tools for assessing nitrogen and phosphorus losses from agricultural systems (Ph.D. Diss.). Univ. of Florida, Gainesville.

Rajesh, C., Reddy, K. S., Naidu, M. V. S., \& Ramavataram, N. (2003). Production and evaluation of compost and vermicompost from solid organic wastes. Asian Journal of Microbiology, Biotechnology, and Environmental Science, 5, 307-311.

Rowell, D. L. (1997). Soil Science: Methods and Applications (p. 350). Longman Singapore Publishers Ltd., Singapore.

Sawhney, J. S., Verma, V. K., \& Jassal, H. S. (2000). Soil physiographic relationship in southeastern sector of submontane tract of Punjab. Agropedology, 10, 6-15.

Sidhu, P. S., Raj, K., \& Sharma, B. D. (1994). Characterization and classification of Entisols in different soil moisture regimes of Punjab. Journal of Indian Society Soil Science, 42, 633-640.

Singh, I. S., \& Agrawal, H. P. (2003). Characteristics and classification of some rice growing soils of Chandauli district of Uttar Pradesh. Agropedology, 13, 11-16.

Swarnam, T. P., Velmurugan, A., \& Rao, Y. S. (2004). Characterization and classification of some soils from Shahibi basin in parts of Haryana and Delhi. Agropedology, 14, 114-122.

Tekalign, M., Haque, I., \& Kamara, C. S. (1988). Phosphorus status of Ethiopian Vertisols: management of Vertisols in Sub-Saharan Africa (pp. 232-252). Proceeding of the Conference Held at International Livestock Centre for Africa.

Tisdale, S. L., Nelson, W. L., Beaton, J. D., \& Havlin, J. L. (2002). Soil Fertility and Fertilizer (7th ed., p. 633). Prentice-Hall of India, Newdelhi.

Wakene, N. (2001). Assessment of Important Physicochemical Properties of Dystric Nitisols under Different Management Systems in Bako area (M.Sc. Thesis, p. 93). Alemaya University, Ethiopia.

Walia, C. S., \& Rao, Y. S. (1996). Genesis, Characteristics and taxonomic classification of some red soils in Uttara Pradesh. Journal of Indian Society Soil Science, 44(3), 576-581.

Walkley, \& Black, C.A. (1934). An examination of different methods for determining soil organic matter and the proposed modifications by the chromic acid titration method. Soil Science, 37, 29-38.

Werner, M. R. (1997). Soil quality characteristics during conversion to organic orchard management. Applied Soil Ecology, 5, 151-167. http://dx.doi.org/10.1016/S0929-1393(96)00139-4

Zinck, J. A. (1990). Soil survey: epistemology of a vital discipline. ITC Journal, 4, 335-351.

\section{Copyrights}

Copyright for this article is retained by the author(s), with first publication rights granted to the journal.

This is an open-access article distributed under the terms and conditions of the Creative Commons Attribution license (http://creativecommons.org/licenses/by/3.0/). 